\title{
ARTIFICIAL TERMINATION OF PREGNANCY IN UKRAINE: BIOETHICAL, PHILOSOPHICAL AND RELIGIOUS ASPECTS
}

DOI: 10.36740/WLek202103231

\author{
Iryna V. Vasylieva, Kateryna 0. Hololobova, Ruslan S. Tsymbaliuk, Olha V. Nechushkina, Viacheslav V. Kobrzhytskyi, \\ Serhii V. Kiriienko, Anna V. Laputko \\ BOGOMOLETS NATIONAL MEDICAL UNIVERSITY, KYIV, UKRAINE
}

\begin{abstract}
The aim: Is to study the levels of influence of the Christian spiritual tradition on the attitude of medical students to abortion, which necessitated a comparative analysis of Christian ethics and the main approaches of secular bioethics regarding artificial termination of pregnancy; analysis of the results of sociological research taking into account the peculiarities of religious self-identification of medical students.

Materials and methods: The complex nature of the studied issue necessitated the application of interdisciplinary approaches, philosophical, general scientific and special sociological methods of collecting, processing and analyzing information. Certain differences between Christian moral guidelines and attitudes towards artificial termination of pregnancy were found in a questionnaire study conducted by a sociological group of the Bogomolets National Medical University (hereinafter - NMU) in 2020. The object of the study were first and sixth year students and postgraduate students of NMU ( $N=375)$.

Results: Based on a comparative analysis of the evaluative judgments of three groups of respondents (1 group - those who identified themselves as Christians; 2 group - those who are uncertain with their attitude towards religion; 3 group - those who consider themselves non-believers) regarding artificial termination of pregnancy, it was found that the attitude of medical students-believers towards this problem differs from the more liberal approaches of the respondents of the second and third groups, and, at the same time, has significant differences with Christian moral guidelines on this issue.

Conclusions: A comparative analysis of the main approaches of secular bioethics and Christian ethics to the issue of artificial termination of pregnancy allows us to conclude that the Christian position is distinguished by the recognition of sacredness, inviolability of human life, inalienable dignity and value of human being from conception to the natural end of life. This determines the special importance of the Christian spiritual tradition in overcoming the manifestations of abortive mentality in contemporary Ukrainian society.
\end{abstract}

KEY WORDS: abortion, bioethics, medical students, Christian ethics, secular bioethics

$\overline{\text { Wiad Lek. 2021;74(3 p.ll):731-735 }}$

\section{INTRODUCTION}

The issue of abortion is one of the most acute ethical and legal problems of the contemporary post-secular world, as it is a violation of a fundamental, basic human right - the right to life. According to the WHO, about 40-50 million abortions are performed annually in the world: approximately 125 thousand abortions per day. The positive dynamics of artificial abortions of pregnancy can be traced in recent years in Ukraine. The number of abortions, according to the Ministry of Health of Ukraine in 2019, amounted to 74 thousand 606, of which 727 were done under the age of full [1].

Overcoming this negative tendency in Ukraine is a particularly difficult process, as Ukrainians (except in the western regions) belong to those peoples to whom abortive "culture" was imposed during the 70-year stay in the USSR. It is a shame, but its consequences have not been overcome to this day. Bishops of the Roman Catholic Church in their message to the 100th anniversary of abortion genocide mention: "Unfortunately, after the collapse of the Soviet Union, Ukraine did not break with this communist legacy and to this day has not created a law that would protect its citizens from conception to natural death. More than 30 million surgical abortions have been performed in Ukraine since independence. During these hundred years since the beginning of the legalization of abortion, the abortion mentality has been formed in society. In the minds of many people, abortion is a common medical procedure, but nevertheless devalues human life, the dignity of women and sows a "civilization of death" in society". [2] Therefore, it is important in solving the issue of abortion not only to provide comprehensive approaches to its solution at the state level, including the regulation of a number of legal norms in accordance with fundamental criteria of morality, but also moral and value transformation, revival of Ukrainian society. Particularly urgent is the formation of the worldview of modern Ukrainian youth, including students of medical institutions of higher education, based on humanistic, universal values, Christian spiritual tradition, which is historically rooted in the history and culture of the Ukrainian people. After all, the moral and ethical principles and strategies of Ukraine's health care system development will largely depend on the position of this group of young people in the coming decades. 


\section{THE AIM}

The aim of this article is to study the levels of influence of Christian spiritual tradition and secular culture on the attitude of medical students towards the issues of abortion. Hence, the tasks are following: to carry out a comparative analysis of the positions of Christian ethics and the main approaches of secular bioethics towards abortion; to analyze the results of sociological research taking into account the peculiarities of religious self-determination of medical students.

\section{MATERIALS AND METHODS}

The complex nature of the studied issue necessitated the application of interdisciplinary approaches, philosophical, general scientific and special sociological methods of collecting, processing and analyzing information. Certain differences between Christian moral guidelines and attitudes towards artificial termination of pregnancy were found in a questionnaire study conducted by a sociological group of the Bogomolets National Medical University (hereinafter - NMU) in 2020. The object of the study were first and sixth year students and postgraduate students of NMU $(\mathrm{N}=375)$.

\section{RESULTS}

An essential feature of bioethics as an integrative direction of modern knowledge and social practice is openness to religious worldview, coexistence of different types of secular version of bioethics and its religious versions: Orthodox, Catholic, Protestant, Jewish, Islamic and other bioethics. $[3$, p. 39, 40].

One of the essential features of Ukraine is a fairly high level of religiousness of population, despite 70 years of experience of forced quasi-atheism. According to a survey conducted by the Razumkov Centre among the Ukrainian citizens as of the end of 2019, the number of people that identify themselves as believers is $66 \%$. Among them, $64.9 \%$ identify themselves with Orthodoxy, 1.6\% - with Roman Catholicism, 9.5\% - with Greek Catholicism, 1.8\% - with Protestantism and $8 \%$ identify themselves as "just a Christian". [4, p.14].

Considering the religious and confessional features of Ukrainian society, the significant influence of Christian spiritual tradition on the development of bioethics and biomedical ethics in Europe, we emphasize the common Christian position regarding artificial termination of pregnancy, its differences from approaches in secular bioethics. As it is known, bioethical assessments of artificial termination of pregnancy are based on two fundamental issues: about the status of the human embryo; the relationship between the mother's right to autonomy, reproductive choice, and the right of the unborn child to life. Although, in our opinion, the current formulation of the issue of the status of the embryo, in the broad sense of this term, does not quite accurately reflect the essence of this problem in bioethics. After all, the emphasis on the embryo (a human being from 2 to 8 weeks of intrauterine development) leaves in the shadow the primary, pre-embryonic stage of development, the moral and ethical assessment, which distinguishes the Christian tradition not only from the moderate (graded) approach in secular bioethics but also from other religious versions [5].

In bioethics, the question of the status of a human embryo is usually related to the answers to question: from what period of fetal development can an embryo be considered human being; does it apply to him and to what extent universal rights, especially the right to life? However, a deeper philosophical question of understanding the essence of man is at the heart of this bioethical issue.

Representatives of the liberal approach understand man as a purely social being, so an embryo is only part of mother's body even in the later stages of fetal development. Therefore, the issue of abortion is considered only in the context of maternal autonomy. Perhaps it is the sociologizing approach to man, and not only the protection of "basic democratic rights of citizens" (Lenin) became the ideological basis for the adoption of the Resolution "On Health" by Bolshevik government on November 18, 1920, which first legalized abortion at a request of a woman. Today, liberal approaches are most actively supported by feminist movements, emphasizing the "basic right of women - the right to their own bodies".

Proponents of a moderate (graduated, centrist) approach assess the status of a human embryo in the dynamics, taking into account the stages of development of a potential human. In the process of its development, the embryo seems to accumulate its right to life, and accordingly reduces the mother's right to autonomous decision-making on abortion. Aristotle was one of the representatives of this approach believing that abortion can be performed as long as a fetus does not become sensitive and mobile.

The position of Christian ethics on abortion and other issues related to the beginning of human life are based on the biblical doctrine of man as the only one in the world created by God in His image and in His likeness (Gen. $1: 26)$, the uniqueness of the divine likeness of human dignity. The principle of human dignity in Christian moral theology is more fundamental and universal than the principle of individual autonomy, because freedom is only one manifestation of the specific nature of man as God's gift. According to the Catholic theologian and bioethicist Ignacio Carrasco de Paula, the deepest basis of human dignity is not that it is individual (unique and inimitable) and not that it is free, but above all that it is transcendent: as the scholastics insisted, capax Dei (capable for God). The idea of the fundamentality of human dignity is inherent in all Christian denominations. [6].

Christian anthropology is characterized by an approach to man in its integrity as a spiritual soul-corporeal creature. The human body is not separated from its "I". Pope John Paul II spoke of a "spiritual body" and a "embodied spirit" [7]. Prominent Orthodox archpastors of the 20th century, the physician and archbishop Luka (Voyno-Yasenetsky) 
Table I. The attitudes of medical students towards the acceptability of induced abortion

\begin{tabular}{cccc}
\hline $\begin{array}{c}\text { «What is your attitude towards an artificial } \\
\text { termination of pregnancy" }\end{array}$ & $\begin{array}{c}\% \text { of those who } \\
\text { identify themselves } \\
\text { as believers }\end{array}$ & $\begin{array}{c}\text { \% of those } \\
\text { who are } \\
\text { undecided }\end{array}$ & $\begin{array}{c}\text { \% of those who do not } \\
\text { identify themselves as } \\
\text { believers }\end{array}$ \\
\hline $\begin{array}{c}\text { Every woman can decide for herself whether to keep } \\
\text { or terminate a pregnancy }\end{array}$ & $45,6 \%$ & $75,0 \%$ & $71,0 \%$ \\
\hline $\begin{array}{c}\text { Abortion is acceptable at the request of a woman only } \\
\text { up to 12 weeks }\end{array}$ & $11,7 \%$ & $12,5 \%$ & $15,0 \%$ \\
\hline $\begin{array}{c}\text { Abortion is acceptable only in cases related to medical } \\
\text { or exceptional social indicators }\end{array}$ & $35,6 \%$ & $12,5 \%$ & $11,2 \%$ \\
\hline $\begin{array}{c}\text { Abortion is acceptable only if a woman's life is } \\
\text { threatened }\end{array}$ & $3,9 \%$ & $0,0 \%$ & $2,8 \%$ \\
\hline $\begin{array}{c}\text { Induced abortion is unacceptable under any } \\
\text { circumstances }\end{array}$ & $3,3 \%$ & $0,0 \%$ & $0,0 \%$ \\
\hline
\end{tabular}

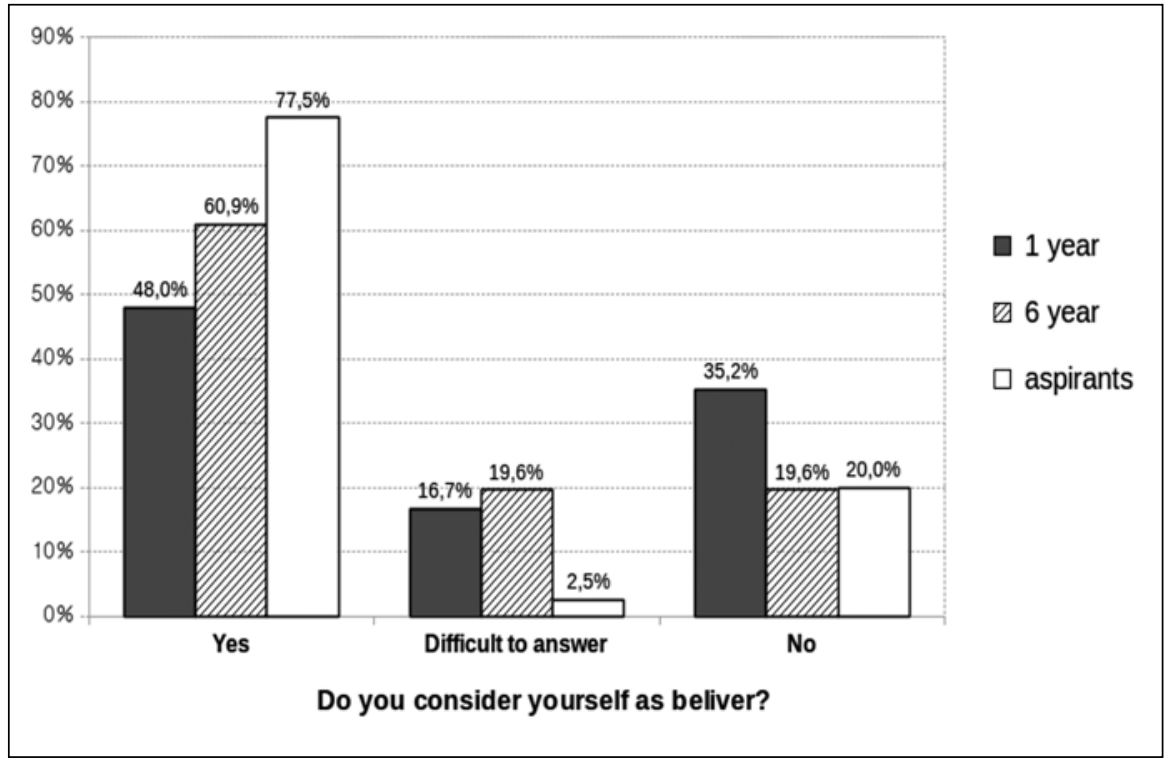

Fig. 1. The attitudes towards religion of medical students of various years of study. Case of Bogomolets National Medical University. and Metropolitan Anthony of Sourozh also developed this approach. Professor of Medicine Voyno-Yasenetsky substantiating the inseparable relationship between the spirit, soul and human body noted that "...spirit forms a body in the embryonic state. All cells of the body inherent spiritual energy and life from the Spirit". [8].

The Christian Eucharistic ethos is characterized by an attitude to life as a priceless gift of God. The contemporary Orthodox theologian Metropolitan John Zizioulas emphasizes the primary understanding and implementation of the Eucharist as an expression of gratitude for the gift of being. [9]. Since life is a fundamental good for man, the morally justified attitude to it is accepting life as a gift that must be cherished, nurtured and loved. [10].

Therefore, today, the common Christian position is the recognition of the inherent dignity and value of the human being from the moment of conception and including all subsequent stages of its intrauterine development. It should be noted that the formation of this approach in Christianity was largely facilitated by the development of science, in particular embryology, genetics. It is no coincidence that Pope Francis qualifies the problem of abortion primarily as a scientific problem.
"It is unethical to hinder the further development of a creature that is already endowed with a full-fledged human genetic code... To have an abortion means to kill a defenseless one" [11]

Certain differences between Christian moral guidelines and attitudes towards artificial termination of pregnancy were found in a questionnaire study conducted by a sociological group of the Bogomolets National Medical University (hereinafter - NMU) in 2020. The object of the study were first and sixth year students and postgraduate students of NMU $(\mathrm{N}=375)$.

Among the respondents, 52.9\% respondents consider themselves believers, $31.6 \%$ consider themselves non-believers and $15.5 \%$ are hesitant to answer the question "Do you consider yourself a believer?" The vast majority of respondents who considered themselves believers identified themselves as Christians (95.2\%), 3.2\% - as Muslims and $1.6 \%$ identified themselves as representatives of other religions.

A statistically significant connection was found between identifying oneself as a Christian and attitude towards abortion $(\mathrm{p}<0.005)$. Respondents who identified themselves as believers were more likely to take a moderate 
Table II. The attitudes of medical students towards the acceptability of induced abortion in relation to years of study. Case of Bogomolets National Medical University.

\begin{tabular}{ccc} 
"What is your attitude towards an artificial termination of pregnancy" & $\begin{array}{c}\% \text { of } \\
\text { respondents } \\
\text { of first year } \\
\text { of study }\end{array}$ & $\begin{array}{c}\% \text { of respondents } \\
\text { of sixth year } \\
\text { of study and } \\
\text { aspirants }\end{array}$ \\
\hline Every woman can decide for herself whether to keep or terminate a pregnancy & $58,0 \%$ & $57,6 \%$ \\
\hline Abortion is acceptable at the request of a woman only up to 12 weeks & $12,5 \%$ & $16,5 \%$ \\
\hline Abortion is acceptable only in cases related to medical or exceptional social indicators & $21,4 \%$ & $23,5 \%$ \\
\hline Abortion is acceptable only if a woman's life is threatened & $3,9 \%$ & $0 \%$ \\
\hline Induced abortion is unacceptable under any circumstances & $1,6 \%$ & $2,4 \%$ \\
\hline
\end{tabular}

approach to the acceptability of induced abortion. Instead, among those who do not consider themselves a believer, the most common is liberal attitude towards acceptability of abortion: $71.0 \%$ respondents believe that every woman can decide for herself whether to keep or to abort pregnancy, because she has the right to control her body (see Table 1).

There is a statistically significant relationship between the year of study and the believer's identification $(\mathrm{p}=0.000)$ : $48.0 \%$ of first-year respondents, $60.9 \%$ of 6 -year respondents and $77.5 \%$ of postgraduate students identified themselves as believers (See Figure 1), which confirms the results of previous studies. In November-December 2013, a survey of students of NMU of 1-6 years of studying $(\mathrm{N}=8259)$ was conducted, the results of which show that contrary to stereotypes that religiosity is associated with low educational and cultural level of the population, the level the religiosity of the respondents does not decrease with the increase in the educational level of medical students.

It is worth noting that the lowest percentage $(2.5 \%)$ of those who are hesitant to answer the question "Do you consider yourself a believer?" is among the postgraduate respondents. That suggests that the worldview self-identification of future doctors becomes more definite with increasing year of study.

Despite this tendency, there was no statistically significant relationship between attitudes towards abortion and year of study $(\mathrm{p}=0.36)$ (see Table 2$)$. The majority of respondents in both the first year of study (58.0\%) and respondents of the 6th year and postgraduate students (57.6\%) follow a liberal approach to the issue of abortion.

\section{DISCUSSION}

The study of the influence of Christian spiritual tradition and secular culture on the attitude of medical students towards the issue of artificial termination of pregnancy indicates the need for further differentiation of groups of respondents. The distinguishing of only three groups on the basis of religious self-identification (those who identified themselves as believers; those who consider themselves non-believers; and those who are undecided) proved insufficient. Medical students who have identified themselves as believers are more inclined to take a moderate approach in assessing the acceptability of induced abortion, as opposed to the liberal approach that prevails in other groups of respondents. Nevertheless, the attitude towards abortion of some medical students who have identified themselves as believers (95.2\% of whom are Christians) does not correspond with Christian morality, which is based on the inviolability of human life from conception at all subsequent stages of fetal development.

Therefore, the group of respondents who identify themselves as believers should be distinguished into at least two subgroups: believers that are characterized by internal religiousness and are focused on Christian spiritual tradition, and believers who are characterized by a fairly high level of focus on secular values of contemporary culture.

\section{CONCLUSIONS}

A comparative analysis of the main approaches of secular bioethics and Christian ethics to the issue of artificial termination of pregnancy allows us to conclude that the Christian position is distinguished by the recognition of sacredness, inviolability of human life, inalienable dignity and value of human being from conception to the natural end of life. This determines the special importance of the Christian spiritual tradition in overcoming the manifestations of abortive mentality in contemporary Ukrainian society. At the same time, the study shows that the values of secular culture, which is largely due to the peculiarities of the modern globalized world, have a significant influence on the formation of evaluative judgments of medical students who have identified themselves as Christians. This highlights the importance of a comprehensive approach to the issue, in particular not only the formation of contraceptive culture among modern youth (which is emphasized in modern society), but also moral education on the basis of universal humanistic values.

\section{REFERENCES}

1. Torik ukrainky zrobyly ponad 74 tys. abortiv, - ofitsiini dani MOZ [Last year, Ukrainian women performed more than 74,000 abortions, according to official data from the Ministry of Health]. (In Ukrainian).

2. Dibrivna E. Sohodni 100 rokiv abortyvnomu henotsydu u sviti. Istoriia ta statystyka 18.11.2020 [Today is the 100th anniversary of abortive genocide in the world. History and statistics]. 2020. (In Ukrainian).

3. Zaporozhan V., Ariaiev M. Bioetyka ta biobezpeka: Pidruchnyk [Bioethics and biosafety: Textbook]. 2013:456. (In Ukrainian). 
4. Derzhava i tserkva v Ukraini - 2019: Pidsumky roku i perspektyvy rozvytku vidnosyn (informatsiini materialy). [State and the Church in Ukraine - 2019: Results of the year and prospects for the development of relations (information materials)]. 2019:70. (In Ukrainian).

5. Vasylieva I., Mozgova N., Bilozor D. et al. The development of bioethics in the context of the christian spiritual tradition. AD ALTA: Journal of Interdisciplinary Research., 2021; 11: 166.

6. Melina L., Herr T., Carrasco de Paula I. et al. Nravstvennoe deistvye khrystyanyna. [The moral action of a Christian]. 2007:159. (In Russian).

7. Giovanni Paolo I.I. Lettera Enciclica Evangelium Vitae [Text] (Citta del Vaticano (25 marzo) . 1995:19.

8. Luka S. (Voino-Yasenetskyi) "Dukh, dusha y telo» [Luka (VoynoYasenetsky). Spirit, Soul and Body]. Avicenna; 2010:199-200. (In Russian).

9. Yoann Z. Obshchenie i inakovost. Novie ocherky o lichnosty y tserkvi [Zizioulas John. Communion \& Otherness: Further Studies in Personhood and the Church (Translated from English)]. 2012:114. (In Russian).

10. Melina L., Herr T., Carrasco de Paula I. et al. Nravstvennoe deistvye khrystyanyna. [The moral action of a Christian]. 2007:148. (In Russian).

11. Berhalio Kh., Skorka A.. Na nebi i na zemli [In heaven and on earth]. 2017:108-109. (In Russian).

The article was performed in framework of research "Research of the theoretical and methodological aspects of philosophy of medicine, phenomenon of medicine, health and human disease" (2020-2022 № state registration 0119U104009).

\section{ORCID and contributionship:}

Irina V. Vasylieva: 0000-0003-3772-5358 A, D, F

Kateryna O. Hololobova: 0000-0003-3343-5978 ${ }^{B, F}$

Ruslan S. Tsymbaliuk: 0000-0002-2024-6425 ${ }^{\text {, F }}$

Olha V. Nechushkina: 0000-0001-6562-6037 B, C, D

Viacheslav V. Kobrzhytskyi: 0000-0002-9127-1791 C,D

Serhii V. Kiriienko: 0000-0003-4100-6698 ${ }^{B, C}$

Anna V. Laputko: 0000-0002-7501-500X ${ }^{B, D}$

\section{Conflict of interest:}

The Authors declare no conflict of interest.

\section{CORRESPONDING AUTHOR}

\section{Irina V. Vasylieva}

Bogomolets National Medical University

13 Taras Shevchenko Boulevard, 01601 Kyiv, Ukraine

tel:+38096-368-24-45

e-mail: ivafilos1403@gmail.com

Received: 28.11 .2020

Accepted: 11.03.2021

A - Work concept and design, B - Data collection and analysis, C - Responsibility for statistical analysis,
D-Writing the article, E-Critical review, F - Final approval of the article 